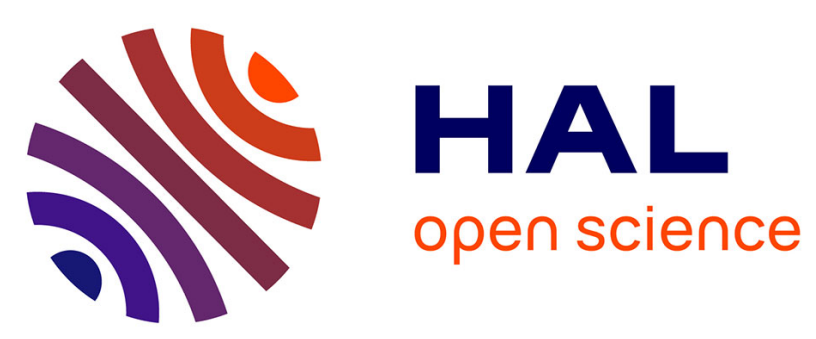

\title{
The Use of the Social Networks by Elderly People in the Czech Republic and Other Countries V4
}

Libuše Svobodová, Martina Hedvičáková

\section{To cite this version:}

Libuše Svobodová, Martina Hedvičáková. The Use of the Social Networks by Elderly People in the Czech Republic and Other Countries V4. 16th Conference on e-Business, e-Services and e-Society (I3E), Nov 2017, Delhi, India. pp.50-60, 10.1007/978-3-319-68557-1_6 . hal-01768532

\section{HAL Id: hal-01768532 \\ https://hal.inria.fr/hal-01768532}

Submitted on 17 Apr 2018

HAL is a multi-disciplinary open access archive for the deposit and dissemination of scientific research documents, whether they are published or not. The documents may come from teaching and research institutions in France or abroad, or from public or private research centers.
L'archive ouverte pluridisciplinaire HAL, est destinée au dépôt et à la diffusion de documents scientifiques de niveau recherche, publiés ou non, émanant des établissements d'enseignement et de recherche français ou étrangers, des laboratoires publics ou privés. 


\title{
The Use of the Social Networks by Elderly People in the Czech Republic and other countries V4
}

\author{
Libuše Svobodová, Martina Hedvičáková \\ University of Hradec Králové, Faculty of Informatics and Management, Department of Eco- \\ nomics, Rokitanského 62, Hradec Králové, 500 03, Czech Republic \\ Libuse.svobodova@uhk.cz, martina.hedvicakova@uhk.cz
}

\begin{abstract}
In the article we will focus on the elderly people in the connection with the utilization of social networks in the Czech Republic, countries of Visegrad Group and the EU 28. Individuals use social networks for sharing materials, photos or videos, communication or posting messages. Very important is also a topic of social isolation that will be discussed in the article. The results of the statistics show that the share of seniors in the Czech Republic has an increasing trend. The utilization of social networks by elderly people has in the Czech Republic also increasing trend except for the second quarter of the 2015 year when a slight decrease was recorded. In comparison with other countries from Visegrad group and the EU 28 the Czech Republic reached lower results in the utilization of social networks. In two evaluated criteria from three the Czech Republic was comparable to Poland. The age groups show that with increasing age there is a declining trend for the use of social networks. $10.1 \%$ of the population from 55 to 64 years and $3.3 \%$ of the population over 65 use social networks in the second quarter of 2015. Data show that almost half of the elderly people that use social networks get connected almost every day.
\end{abstract}

Keywords: Elderly people, Social Networks, Statistics, Utilization.

\section{Introduction}

The discussed topic of the utilization and role of social software applications with the focus on the elderly people will be solved in the article. Elderly people have an impact not only on the economy, health care but also on social relations and other important areas. Despite the fact that ten years ago, there was no usual use of ICT by elderly people, the situation is in recent years evolving and changing.

Learning and using information and communication technologies (ICT) such as computer technologies and internet by the elderly is seen as an important demand for their integration in daily life and as a factor related to active aging. [1] Elderly people can on the Internet read online news, newspapers and magazines [22], find information about goods and services, travel and accommodation, health, or search information in the encyclopedias. They can also share information, communicate with others and obtain the above mentioned information via social networks. 
Also people that have medical or other problems and have problems to communicate face to face may thanks to these services get again engaged in an active lifestyle [7], [23]. Social networks help in the social isolation [24]. A lot of elderly people have problems with the movement. They can be in the connection with their families and other people via social networks. [25] Active ageing but also social isolation are the most important facts why elderly people use social networks.

Due to a growing number of elderly people, it is a necessity to create the cities that are aware of the special needs of all their citizens including the needs of aging populations. [2] Despite the fact that urban population is ageing, there is a paucity of studies exploring how ICTs can support older people's living in urban areas. Thus far, visions of smart cities for older people have focused on removing architectural barriers and making physical environments more age-friendly, by considering age-related declines in functional abilities, especially mobility. [3] The aging population comes with many challenges for smart cities - across social, financial, economic, and political dimensions. Managing healthcare quality and costs for this demographic is one of the key focus areas but there are other areas that our Smart Cities majors and municipal councils should consider. [4] The Internet of Everything will allow new business models based on Internet of Things technologies. Sensor technology is increasingly being used in cities to provide us with information about how traffic is flowing, where water pipes are leaking and how much rubbish is going in bins. How looks like the situation in utilization of social networks in the Czech Republic and in other countries of Visegrad four by elderly people will be solved in the next part of the article.

\subsection{Development of population in the Czech Republic}

The share of seniors in the Czech population has been steadily increasing since 1985 (from the level of 12\%). By the end of the 20th century, the growth was slow (to $13.9 \%$ in 2000-2003), but thereafter it accelerated. The share significantly rose especially since 2007 , in the connection with baby boomers born in the 40 s of the 20th century across the border 65 years of age. During the years 2004-2014, the share of seniors increased from $14 \%$ to almost $18 \%$.

Table 1. The characteristics of the age composition of 1984, 1994, 2004 and 2014 (to 31. 12.)

\begin{tabular}{lllll}
\hline Index & 1984 & 1994 & 2004 & 2014 \\
\hline The share of seniors (in\%) & 11,8 & 13,1 & 14 & 17,8 \\
The share of persons aged 80+ on 65+ years (in\%) & 17,9 & 21,0 & 21,5 & 22,3 \\
Age index & 50,3 & 69,6 & 94,0 & 117,4 \\
Average age (in years) & 35,6 & 37,0 & 39,8 & 41,7 \\
Median age (in years) & 33,9 & 36,2 & 38,7 & 41,1 \\
The number of seniors aged 65+ years (in mil.) & 1,22 & 1,36 & 1,43 & 1,88 \\
The number of seniors aged 80+ years (in thousands) & 219 & 285 & 308 & 419 \\
\hline
\end{tabular}

Source: [5]

The last presented data (to 31. 12. 2014) states that the proportion of people over 65 years of age is in the general population $17.8 \%$. The current number of 1.88 mil- 
lion is about 243 thousands higher than at the beginning of 2011. Also the highest increases in the age groups were concentrated in the population of the age group of seniors over 65 years. Those increased by 54,900 during 2014. Due to the aging population this issue is very serious in solving economic, social and other areas.

\section{$2 \quad$ Literature review}

Social software applications, social media and social networks play integral role in everyday life of a lot of people all over the world. This topic is also very often discussed but it is not so often connected with the elderly people.

Internet is an ever-growing communication net that connects the most computer systems of the world. It is also the growing technology which is used by people like the information storage, sharing, and easy access. Computer and internet are large communication vehicles of nowadays and future that provide an easy, quick, cheap and safe access to a lot of information. [9]

A sociologist J. A. Barnes (1954) is considered to be the author of the definition of the social network. The term social network is associated with the Internet and directly with the social networks on the Internet. [10]

Social network on the Internet is considered to be a group of people who communicate and share documents and information on users. The Social Network concept is described and defined by Boyd and Ellison: Social networking is defined as a web service that allows individuals to create a public or semi-public profile within the bounded system, create a group of users with whom they share a connection, and browse the list of own connections and that created by other users of the system. The nature and terminology of these connections may be different network from the network. [11]

Social media refers to the means of interactions among people in which they create, share, and exchange information and ideas in virtual communities and networks. [12] Furthermore, social media depends on mobile and web-based technologies to create highly interactive platforms through which individuals and communities share, co-create, discuss, and modify user-generated content. It introduces substantial and pervasive changes to communication between organizations, communities, and individuals. [13] Kaplan and Haenlein [14] define social media as a group of Internetbased applications that build on the ideological and technological foundations of Web 2.0 , and that allow the creation and exchange of user-generated content.

On Web 2.0 summit presented O'Reilly and Battelle Web Squared: Web 2.0 Five Years On [15]. Chief among our insights was that "the network as platform" means far more than just offering old applications via the network ("software as a service"); it means building applications that literally get better the more people use them, harnessing network effects not only to acquire users, but also to learn from them and build on their contributions. From Google and Amazon to Wikipedia, eBay, and craigslist, we saw that the value was facilitated by the software, but was co-created by and for the community of connected users. Since then, powerful new platforms like YouTube, Facebook, and Twitter have demonstrated that same insight in new ways. 
Web 2.0 is all about harnessing collective intelligence. Collective intelligence applications depend on managing, understanding, and responding to massive amounts of user-generated data in real time.

Chen and Schulz [16] presented review study focused on utilization of social media in the connection with social isolation among elderly people. Evidence indicates that contemporary information and communication technologies (ICT) have the potential to prevent or reduce the social isolation of elderly people via various mechanisms. ICT was found to alleviate the elderly's social isolation through four mechanisms: connecting to the outside world, gaining social support, engaging in activities of interests, and boosting self-confidence.

Gonzalez [17] et. al. focused on the analysis of the main habits of use and consumption of new technologies by older people, in particular, the level of knowledge and their level of education.

\section{$3 \quad$ Methodology and goals}

Elderly people as a term doesn't have a single definition; there is no general agreement when the person is considered old. Most developed world countries have accepted the chronological age of 65 years as a definition of 'elderly' or older person. At the moment, there is no United Nations standard numerical criterion, but the UN agreed cut off is 60+ years to refer to the older population. [6] Casado-Munoz et. al. presented in their paper [7] elderly people from 55 years. In our paper will be presented data from 55+ when data is known. Montaa et. al. [8] classify in the research young olds from 61-70 years and middle olds (71 and over).

The goal of the article is to analyse the situation in the field of utilization of social software applications by elderly people in the Czech Republic and to compare the use of social networks in the Czech Republic with other countries V4. Visegrad group is the association composed of the Czech Republic, the Slovak Republic, Poland and Hungary. It focuses on foreign policy activities and the group aims to promote cooperation and stability in the broader region of Central Europe.

The following scientific questions will be solved in the article:

- At least $5 \%$ of elderly people in the Czech Republic were using social networks in 2015.

- The percentage of users of social networks by elderly people is increasing every year in the last three years.

- At least $1 / 2$ of elderly people who use social networks attend them regularly.

While composing this article, especially secondary sources from the various authors but also official statistics by the Eurostat and Czech Statistical Office were used. Information was also obtained from expert press, conferences, seminars and other sources. The obtained data were further sorted, processed in custom tables, clearly set-out diagrams, and further analysed to provide a basic overview of the relevant problem area. 
Data that were gained from Eurostat [18] refer to the last 3 months before the survey, for private purposes. Participating in social networks: creating user profile, posting messages or other contributions to facebook, twitter, etc. Data given in this domain [18] are collected annually by the National Statistical Institutes and are based on Eurostat's annual model questionnaires on ICT (Information and Communication Technologies) usage in households and by individuals. The aim of the European ICT surveys is the timely provision of statistics on individuals and households on the use of Information and Communication Technologies at European level. Data for this collection are supplied directly from the surveys with no separate treatment. The survey is a general population / household survey.

The detailed description of methodology and data are discussed directly by tables and graphs.

\section{$4 \quad$ Results}

\subsection{International comparison}

Statistics were obtained from Eurostat sources. Data are always stated for years that were statistically processed. Always refer to all "All Individuals". Data only for 65+ are not available at the moment. Selected data for the EU 28 and the Czech Republic together with the countries of the Visegrad Group were chosen for comparison because those countries are close to the Czech Republic. Data [18] are always given in $\%$. Tables are completed with graphs which will help in faster-after straightening.

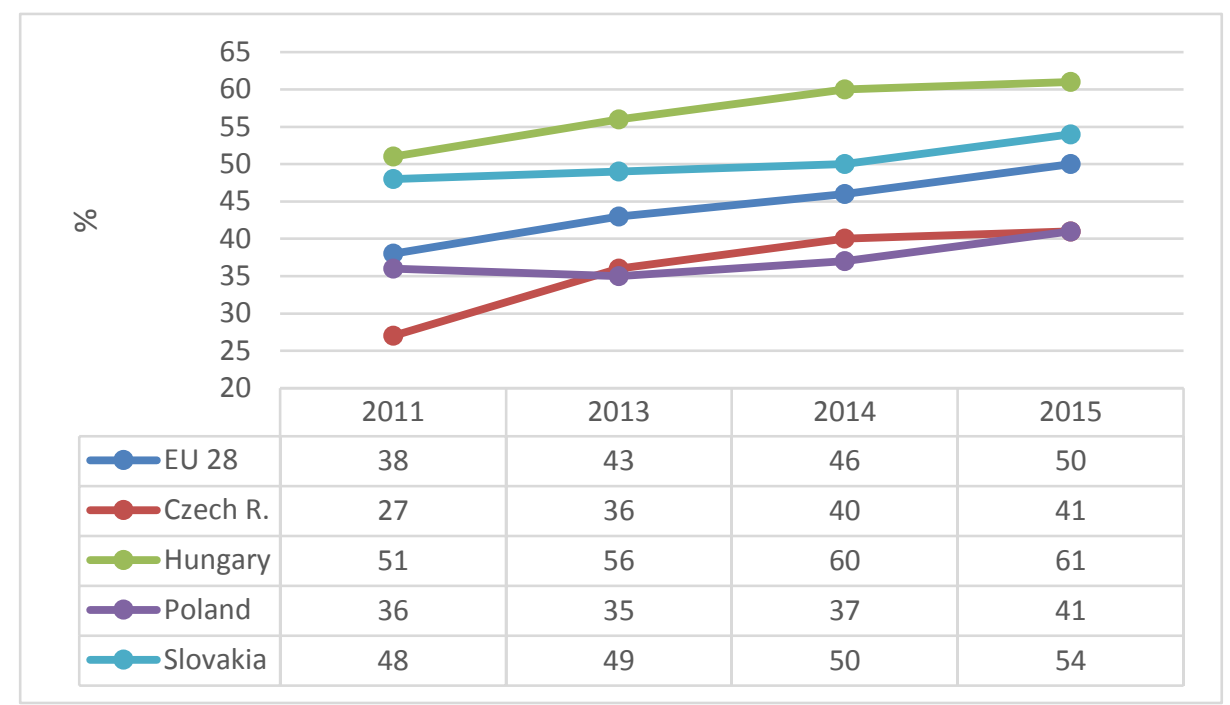

Fig. 1. Participating in social networks (creating user profile, posting messages or other contributions to Facebook, Twitter, etc.). Source own elaboration based on [18] 
The figure 1 contains data about Participating in social networks. It includes creating user profile, posting messages or other contributions to Facebook, Twitter etc. Even though the use of social networking is still growing, data shows that the Czech Republic was in a comprehensive comparison almost always in the last position. Social networks are being used the most over the evaluated period in Hungary, followed by Slovakia, EU 28 and similar results as the Czech Republic reached Poland.If we additionally add into comparison professional networks, percentages are slightly raised. There are not significant changes in the comparison of the trend, see figure 2. Only $0.5 \%$ of pensioners in the Czech Republic use professional networks, see fig 2.

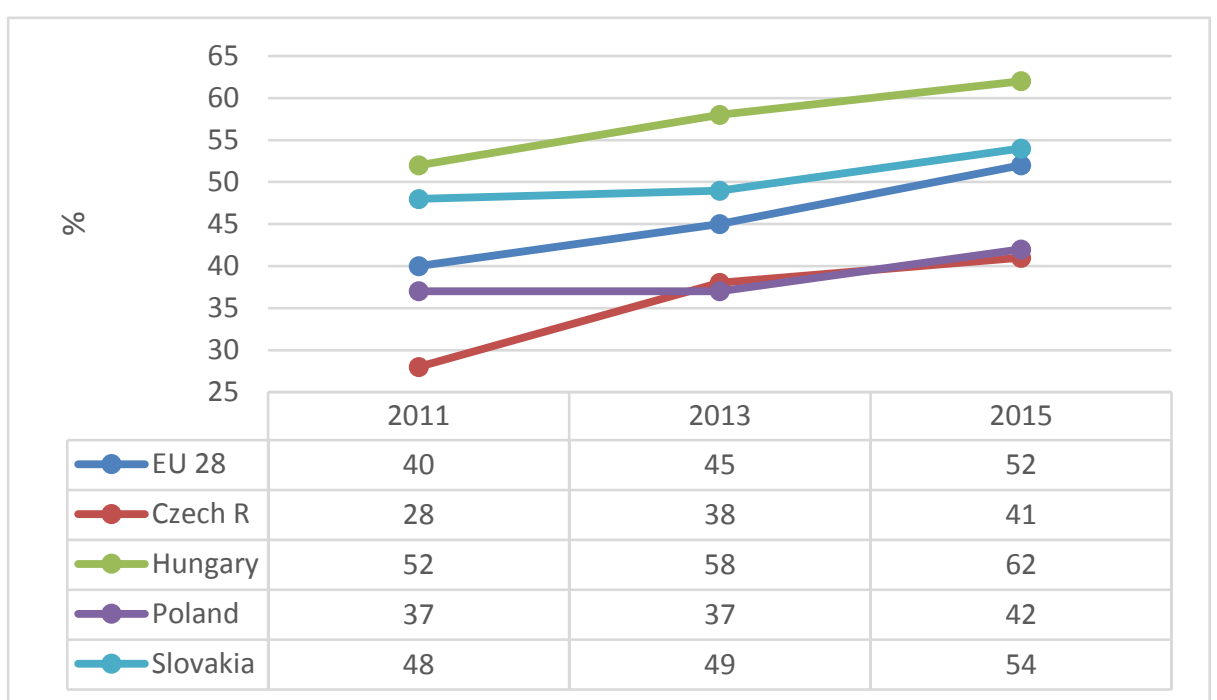

Fig. 2. Participating in social or professional networks. Source: own elaboration based on [18]

Posting messages to social media sites or instant messaging is the next researched topic, see fig. 3 .

At first glance is it is evident from the graph and table in figure 3 that the Czech Republic is again on the last place and lags behind other countries. Despite the fact that from 2009 to 2012 posting messages increased by $3 \%$, other countries grew much more. The highest increase was 12\% in the EU 28, but the EU 28 reached in the 2012 the second lowest percentage in the reference sample. About $18 \%$ to $47 \%$ increased messaging in Slovakia, $9 \%$ to $43 \%$ in Hungary and increase by $7 \%$ to $42 \%$ in Poland. 


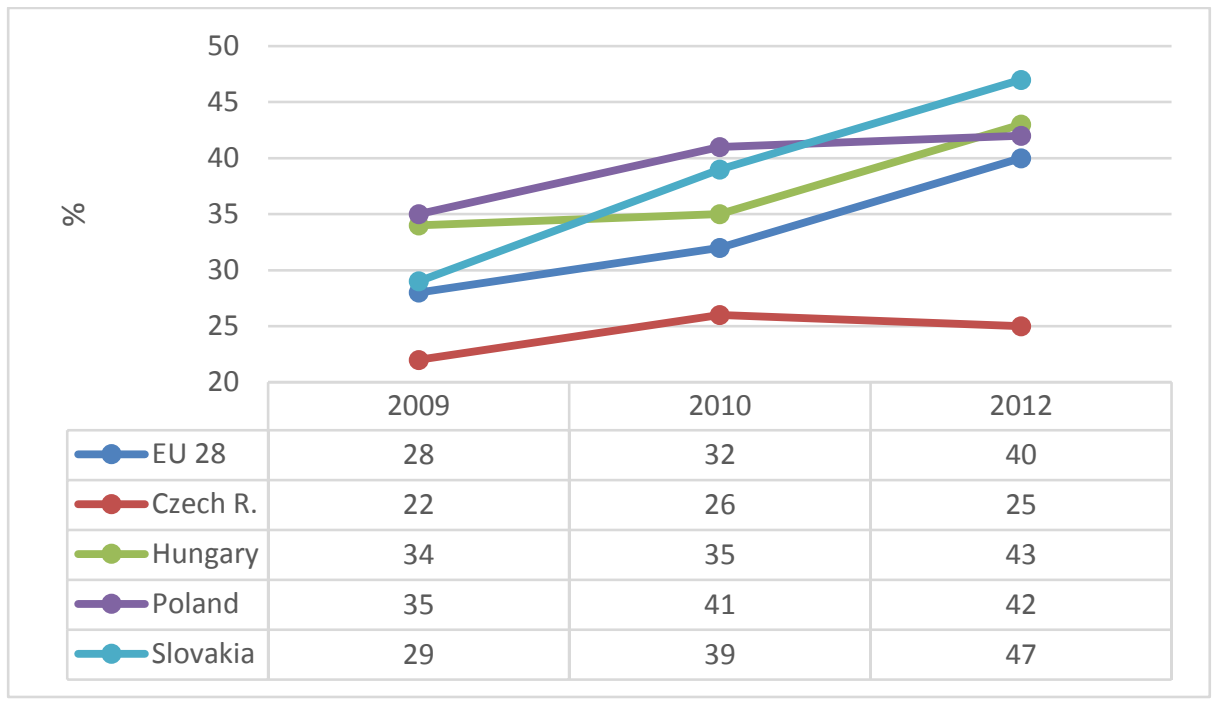

Fig. 3. Posting messages to social media sites or instant messaging. Source own elaboration based on [18]

The connection of social networks with elderly people will be solved in the next part of the article.

\subsection{Czech Republic}

The table 2 shows the reasons for utilization of the Internet with focus on the use of social networks. Presented results are divided for citizens over 16 years. Furthermore, according to gender over 16 years and then by age and according to economic activity status. Two age groups - from 55 to 64 years and 65 years were chosen for comparison. Furthermore, statistics are given for employed, unemployed and pensioners. Both age groups in all economic activity statuses can be represented in the Czech Republic. It can also for example happen that pensioner is employed.

In detailed table at Czech Statistical Office is at the first glance evident that young adults are still the most likely to use social media. $37.4 \%$ of the population over 16 years uses social networks according to the Czech Statistical Office. $40.7 \%$ individuals aged 16 to 74 years uses social networks according to the Eurostat. In the event that we focus on the individuals who use the Internet, the percentage will rise. $49.5 \%$ of the population that uses the Internet, uses social networks according to the Czech Statistical Office. For gender, there were no significant differences. Data shows that women and men use social networking sites at comparable rates. The similar results were gained also in the Pew Research Center [20]. A slightly higher percentage of men, $37.6 \%$ use social networks. Women's use is smaller by $0.3 \%$. In case that we focus again on the group using the Internet, the percentage will rise again. $48.2 \%$ of men using the Internet are also using social networks. Representation of women stand higher by $50.8 \%$. 
Table 2. Individuals in the Czech Republic using the Internet for private purposes for selected activities in the field of communication; Q2 2015

\begin{tabular}{lcccccccc}
\hline & \multicolumn{3}{c}{$\begin{array}{c}\text { Participation in social } \\
\text { networks - total }\end{array}$} & \multicolumn{5}{c}{$\begin{array}{c}\text { from that every day or almost } \\
\text { every day }\end{array}$} \\
\cline { 2 - 8 } & in thous. & $\%^{1)}$ & $\%^{2)}$ & in thous. & $\%$ & $\%^{1)}$ & $\%$ \\
& 3284,6 & 37,4 & 49,5 & 2218,8 & 25,3 & 33,4 & 67,6 \\
Total 16+ & 3282,5 & 40,7 & 50,0 & 2218,8 & 27,5 & 33,8 & 67,6 \\
Total 16-74* & & & & & & & \\
Gender & 1609,3 & 37,6 & 48,2 & 1103,0 & 25,7 & 33,0 & 68,5 \\
Male 16+ & 1675,3 & 37,3 & 50,8 & 1115,8 & 24,9 & 33,8 & 66,6 \\
Female 16+ & & & & & & & \\
$\quad$ Age group & 144,1 & 10,1 & 14,9 & 66,0 & 4,6 & 6,8 & 45,8 \\
55-64 years & 60,1 & 3,3 & 11,7 & 27,3 & 1,5 & 5,3 & 45,4 \\
65+ & 2164,4 & 43,3 & 47,2 & 1340,7 & 26,8 & 29,2 & 61,9 \\
Economic activity status & 100,2 & 38,6 & 52,2 & 72,4 & 27,9 & 37,8 & 72,3 \\
Employed & 83,2 & 3,7 & 11,4 & 38,0 & 1,7 & 5,2 & 45,7 \\
Unemployed & & & & & & & \\
Pensioners & & & & & & & \\
\hline
\end{tabular}

Source [19]

1) As a $\%$ of total number of individuals in a given socio-demographic group

2) As a $\%$ of total number of Internet users in a given socio-demographic group

3) As a $\%$ of total number of social network users

* The data presented by Eurostat for the Czech Republic covers only individuals aged 16 to 74 years.

The age groups shows that with increasing age is a declining trend for the use of social networks. While $88.7 \%$ of the population from 16 to 24 years benefited in 2015 from utilization of social networks, in the age group 15-34 it was $72.3 \%$, from $35-44$ it was $23.9 \%$. $10.1 \%$ of the population from 55 to 64 years and $3.3 \%$ of the population over 65 use social networks.

Other statistics show that nearly $68 \%$ of users who use social networks attend these application every day or almost every day. For older population this percentage decreases by almost a third, to $45.4 \%$. A similar percentage, $45.7 \%$ are also listed among pensioners. From the data it is evident that almost half of the elderly people that use social networks are connected each or almost every day.

In the case that we will focus on the development in time it is from Table 3 evident that in almost all of the analysed groups in the article increased using the social networks. The exception is the last year when in the last two age groups has slightly decreased using of social networks, as well as a decline among pensioners. The available statistical data from the Czech statistical office from 2011 used social networks $6 \%$ of people 55 to 64 years, and only $1 \%$ of the population over 65 years. 
Table 3. Individuals using social networks in the Czech Republic

\begin{tabular}{lccc}
\hline & 2013 & 2014 & 2015 \\
\hline Total 16+ & 34,3 & 36,9 & 37,4 \\
Total 16-74 years & 36,3 & 40,0 & 40,7 \\
Age groups & & & \\
55-64 let & 9,7 & 10,5 & 10,1 \\
$65+$ & 2,0 & 3,5 & 3,3 \\
Pensioners & 3,3 & 4,1 & 3,7 \\
\hline
\end{tabular}

\section{Source [19]}

Share in the total number of individuals in a given group

Another interesting statistics shows that a small percentage of the population uses professional networks, see tab. 4 . Only $4.1 \%$ of the population over 16 years use professional networks by the Czech Statistical Office. Men outnumber women from $5.1 \%$ to $1.9 \%$. In the case that we focus on elderly people, only $0.4 \%$ over 65 use professional social networks and $1.9 \%$ from 55 to 64 years. In the event that we will focus on economic activity status, $0.5 \%$ of pensioners use social networks. The table also shows the data for employed and unemployed. Results are surprising. $2.4 \%$ unemployed uses social networks.

Table 4. Individuals using professional social networks in the Czech Republic

\begin{tabular}{l|c|c|c}
\hline \multirow{2}{*}{} & \multicolumn{3}{|c}{ participation in professional networks } \\
\cline { 2 - 4 } & in thous. & $\%^{1)}$ & $\%^{2}$ \\
\hline Total 16+ & 362,6 & 4,1 & 5,5 \\
Total 16-74* & 359,8 & 4,5 & 5,5 \\
Gender & & & \\
Males 16+ & 216,7 & 5,1 & 6,5 \\
Females 16+ & 145,9 & 3,2 & 4,4 \\
Age group & & & \\
55-64 years & 27,7 & 1,9 & 2,9 \\
65+ & 6,7 & 0,4 & 1,3 \\
Economic activity status & & & \\
Employed & 285,4 & 5,7 & 6,2 \\
Unemployed & 6,2 & 2,4 & 3,2 \\
Pensioners & 10,5 & 0,5 & 1,4 \\
\hline
\end{tabular}

Source [19]

1) As a $\%$ of total number of individuals in a given socio-demographic group

${ }^{2)}$ As a $\%$ of total number of Internet users in a given socio-demographic group 


\section{$5 \quad$ Conclusion and Discussion}

The user group of elderly people is a still growing group and hence depicts an interesting research area. Individuals 55 to 74 years old has the growing trend from 2007 in the indicator last internet use: in last 3 months.

The results show that even though social software applications are used by a small percentage of elderly people, their number and percentage increases. $3.7 \%$ individuals $65+$ used the social networks in the second quarter of $2015.11 .4 \%$ individuals $65+$ who use the Internet visit also social networks. $1.7 \%$ of all elderly people regularly attend social networks. 5.2\% who use the Internet at the same time use social networks regularly and $45.7 \%$ who visit social networks access networks each or almost every day.

Participating in social networks (creating user profile, posting messages or other contributions to Facebook, Twitter, etc.) was in the compared years in the Czech Republic and in Poland on the lowest levels in Visegrad 4 and in EU 28 (mean). In the Czech Republic and in Poland participate on social networks more than 35\%, in EU28 it was $50 \%$, in Slovakia $54 \%$ and the highest use presented Hungary with $61 \%$. The development was in all countries similar instead Poland. Due to the above mentioned facts it is not possible to confirm scientific questions which were stated in the second chapter of the article. In the Czech Republic is also rising the percentage of the individuals aged 65 to 74 old people that have to use internet.

The next researched topic was the utilization of social networks in the Czech Republic and in other countries of Visegrad Group and the EU28 average. It was found out that social networks were used in the followed period less often in the Czech Republic than in other countries involved into the comparison. The question can be why? Do pensioners have digital literacy or necessary equipment? Are there the courses for seniors in the large cities like Hradec Králové?

Also for these reasons we recommended to promote information and digital literacy to citizens and to invest in further education in this field. Information on the courses that are focused on the elderly people and computer literacy in Hradec Králové are presented in [26]. Most elderly people watch TV and read newspapers and for that reason promotion could focus on those channels, but also on other sources. This topic is also interesting due the SMART cities.

The question in the discussion is whether the increasing number of pensioners in the Czech Republic will increase the number of Internet users and social networking for $65+$ or will be still personal communication significantly more used. It is expected that the increase in percentage of elderly people who will use advanced technologies will continue. Therefore, the next question might be, whether growing population in 55-64 group which currently uses advanced technologies by $20 \%$ more than the $65+$ group will keep this trend. The influence of family and health status on the utilization of social networks to communicate with other people or more detailed mentioned benefits gained from utilization of advanced technologies by elderly people may be other areas of research. Next important topic can be social networks and clustering [21]. 


\section{Acknowledgment}

This study is supported by internal research project No. 2103/2017 Investment evaluation within concept Industry 4.0 at Faculty of Informatics and Management, University of Hradec Kralove, Czech Republic. We would like to thank student Marta Martinova for cooperation in the processing of the article.

\section{References}

1. Sitti S, Nuntachampoo S (2013) Attitudes towards the use of ICT training curriculum for Thai elderly people. Procedia - Social and Behavioral Sciences. Vol. 103. pp. 161-164

2. Skouby KE, Kivimäki A, Haukipuro L, Lynggaard P, Windekilde I. Smart Cities and the Ageing Population. http://www.wwrf.ch/files/wwrf/content/files/publications/outlook/Outlook12.pdf

3. Righi V, Sayago S, Blat J. Urban ageing: technology, agency and community in smarter cities for older people. http://www.dtic.upf.edu/ ssayag/preprint/C\&T15_UrbanAgeing_AAV.pdf

4. Smart Cities Are Vital to Cope with the Aging Population. https://datafloq.com/read/smart-cities-vital-cope-with-aging-population/1205

5. Statistics about population. http://www.statistikaamy.cz/2015/05/praha-uz-neni-nejstarsimkrajem/

6. Health statistics and information systems, Definition of an older or elderly person. http://www.who.int/healthinfo/survey/ageingdefnolder/en/

7. Casado-Munoz R, Lezcano F, Rodriguez-Conde MJ (2015) Active Ageing and Access to Technology: An Evolving Empirical Study. Comunicar. 45, pp. 37-46

8. Montaa M, Estanyol E, Lalueza F (2015) Our seniors' challenge to the new media: uses and opinions. Profesional de le Informacion. 24(6), pp. 759-765

9. Ramazan A, Kazaz N, Basa B (2013) The internet addiction of Kosovo and Turkey Elderly People. Procedia - Social and Behavioral Sciences. Vol. 103, pp. 1104-1117.

10. Barnes J. (1954) Class and Committees in a Norwegian Island Parish. Human Relations, (7) pp. 39-58

11. Boyd DM, Ellison NB (2007) Social Network Sites: Definition, History, and Scholarship, Journal of Computer-Mediated Communication, 13(1), pp. 210-230

12. Ahlqvist T, Bäck A, Halonen M, Heinonen S. (2008) Social media road maps exploring the futures triggered by social media. VTT Tiedotteita - Valtion Teknillinen Tutkimuskeskus, 2454: 13

13. Kietzmann HJ, Hermkens K. (2011) Social media? Get serious! Understanding the functional building blocks of social media. Business Horizons, 54: 241-251

14. Kaplan AM, Haenlein M (2010) Users of the world, unite! The challenges and opportunities of social media, Business Horizons, vol. 53(1), p. 61

15. O'Reilly T, Battelle J. Web Squared: Web 2.0 Five Years On. http://www.web2summit.com/web2009/public/schedule/detail/10194

16. Chen YRR, Schulz PJ (2016) The Effect of Information Communication Technology Interventions on Reducing Social Isolation in the Elderly: A Systematic Review. Journal of medical internet research. 18(1)

17. Gonzalez-Onate C, Fanjul-Peyro C, Cabezuelo-Lorenzo F (2015) Use, Consumption and Knowledge of New Technologies by Elderly People in France, United Kingdom and Spain. Comunicar. 45, pp. 19-27 
18. Eurostat

http://ec.europa.eu/eurostat/statisticsexplained/index.php/Digital_economy_and_society_statistics_-

households_and_individuals

19. Czech Statistical Office, 2015. https://www.czso.cz/csu/czso/cinnosti-provadenejednotlivci-na-internetu

20. Pew Research Center. Social Media Usage 2005-2015. http://www.pewinternet.org/2015/10/08/social-networking-usage-2005-2015/

21. Hedvicakova M, Pozdilkova A, Stranska PK, Svobodova L (2016) Analysis of mobile social networks using clustering. Advanced Science Letters. 22(5-6) pp. 1273-1277

22. Gonzalez-Onate C, Fanjul-Peyro C, Cabezuelo-Lorenzo F (2015) Use, Consumption and Knowledge of New Technologies by Elderly People in France, United Kingdom and Spain. Comunicar. 45, pp 19-27.

23. Llorente-Barroso C, Vinaras-Abad M, Sancher-Valle M (2015) Internet and the Elderly: Enhancing Active Ageing. Comunicar. 45, pp 29-36.

24. Chen YRR, Schulz PJ (2016) The Effect of Information Communication Technology Interventions on Reducing Social Isolation in the Elderly: A Systematic Review. Journal of medical internet research. 18(1).

25. Montaa M, Estanyol E, Lalueza F (2015) Our seniors' challenge to the new media: uses and opinions. Profesional de le Informacion. 24(6), pp 759-765.

26. Autumn Internet courses for seniors

http://www.hradeckralove.org/urad/internet-pro-seniory

seniorhk.cz. 